\title{
Modern Sovereign Money-Part II: A Synthesis of the Chicago Plan, Sovereign Money, and the Modern Money Theory
}

\author{
Christian Etzrodt \\ International College of Liberal Arts, Yamanashi Gakuin University, Kofu, Japan \\ Email: etzrodtc@hotmail.com
}

How to cite this paper: Etzrodt, C. (2018) Modern Sovereign Money-Part II: A Synthesis of the Chicago Plan, Sovereign Money, and the Modern Money Theory. Open Journal of Social Sciences, 6, 116-135. https://doi.org/10.4236/jss.2018.69008

Received: August 8, 2018

Accepted: September 2, 2018

Published: September 5, 2018

Copyright $\odot 2018$ by author and Scientific Research Publishing Inc. This work is licensed under the Creative Commons Attribution International License (CC BY 4.0).

http://creativecommons.org/licenses/by/4.0/

\section{c) (i) Open Access}

\begin{abstract}
In the first part of this series, I demonstrated that the current fractional reserve banking system produces a fundamental conflict of interest between private banks and society. The aim of this second part is to describe three radical solutions to this interest conflict. The Chicago Plan and the Sovereign Money approach propose to prohibit private banks to create money by abolishing fractional reserve banking. The Modern Money Theory on the other hand tries to challenge the current economic systems as a whole based on chartalist ideas. All three approaches have serious deficits. However, they are complementing each other well. The Modern Money Theory solves the main problem of the Chicago Plan and the Sovereign Money proposal, whereas the latter two solve the major issues of the former. I will outline a synthesis of those three theories in order to overcome the interest conflict between the private banks and society.
\end{abstract}

\section{Keywords}

Chicago Plan, Sovereign Money, Positive Money, Modern Money Theory, Public Banking

\section{Introduction}

The collapse of the global financial markets in 2008 and the following recession has given us a unique opportunity to think about the efficiency of our current economic system. As I have shown in the first part of this series [1], a careful analysis of the system-related causes of the crisis reveals a fundamental conflict between the private banks and society. Private banks (non-government owned banks) can increase their profits by creating more and more money through 
credit. This, however, also increases the risk of bank runs, if a large amount of borrowers default. Bank runs again have a very negative impact on society. If the private banks are bailed out, then the taxpayers have to pay for the risk-seeking behavior of bankers. Or if the government lets the private banks fail, then a sudden credit crunch could lead to a serious recession in the real economy.

Two theories explain how the private banks create money. The money multiplier model emphasizes that private banks have to wait until customers deposit their money in order to use those deposits to make loans. The money supply is controlled by the central bank through reserve requirements. However, private banks can circumvent those regulations entirely through securitization. The second theory is the endogenous money theory, which claims that private banks do not need to wait for customers to deposit their money. The accounting rules of double-entry bookkeeping allow the banks to create loans (as an asset) by counter-balancing it with fictitious deposits in the name of the borrowers (as a liability). Here, the money supply is endogenously determined by the demand for credit and is not anymore under the direct control of the central bank. The endogenous money theory is clearly a much more accurate description of reality. However, for a policy discussion, it is important to keep both models in mind. A proposal with would only prohibit private money creation as described in the endogenous money theory would not solve the problem, because private banks could still take excessive risks in the money multiplier model through securitization. Any real solution to the problem would have to either close the loopholes or prohibit also private money creation as described in the money multiplier model.

As I have shown in the first part [1], conventional reforms of the banking system are very unlikely going to solve the interest conflict between private banks and society, because the private banks would always find ways to evade regulations. Therefore, it becomes reasonable to consider some unconventional (and more radical) options. Instead of allowing the private banks to create money through fractional reserve banking, it could be argued that the ability to create money should be a state monopoly (cf. [2], pp. 358-359). If a normal citizen tried to create (counterfeits) money, he/she would go to prison. Why then do we allow private banks to create over $97 \%$ of our money out of thin air ([3], p. 369)? One argument could be that we give private banks this extraordinary privilege to create money, because they fulfil an important function in the economy. However, the too-big-to-fail banks are not fulfilling their functions for the economy. They do not transfer the money from the depositors to the businesses who want to invest, because it is much more profitable for them to speculate with the depositors' money ([4], p. 6). And they have strong incentives to create bubbles, because a bubble fuels the demand of debts, which again allows a higher leverage of private banks. Investors are more willing to finance their investment with debt, if prices (e.g. the value of a house) compared to the costs of borrowing the money increases faster, because they could always sell their investment with 
profits. Of course, this logic only works until the bubble bursts. Therefore the private banks neither support real economic growth (cf. [4], p. 7) nor price stability (cf. [2], p. 361; [5], p. 4). But if the current banking system is not fulfilling their core functions for the economy, why should we accept the risks they are creating for the whole society?

In the following, I will discuss the Chicago Plan, the Sovereign Money approach, and the Modern Money Theory. And finally, I will propose a synthesis of these three approaches, which would indeed much better solve major problems of our current economic system: growth, employment, and price stability.

\section{Chicago Plan}

The Chicago Plan was developed as a response to the Great Depression during Roosevelt's New Deal banking reform. The first version was written by prominent economists at the University of Chicago in 1933 under the leadership of Frank Knight ([6], p. 4f; [7], p. 7). Later Henry Simons [8] [9], Irving Fisher [10], Milton Friedman [11] [12] [13], and Jaromir Benes and Michael Kumhof [14] published proposals with slightly different content. The common element of all these proposals was the aim to eliminate the private banks' ability to create money by requiring them to hold full reserves for their customers' deposits. Such a move would reduce the risk for the banks' customers, since they would not need to worry anymore about bank runs, because there would always be adequate cash for the withdrawals available. It would furthermore decouple the activities of saving and lending. In fact, the Chicago Plan proposed the separation of two types of private banks: money banks, which would keep the deposits and provide services for fees, and credit investment trusts, which would still be able to provide loans ([7], p. 7; [14], p. 17).

The basic idea was to allow the credit investment trusts to continue to create credit, but purely as intermediaries: "first obtaining funds and subsequently lending these out" ([7], p. 7; cf. [14], p. 34). However, in regard to the exact organization of bank lending those proposals differed significantly. On the one hand, Fisher's [10] proposal would give the credit investment trusts the right to finance loans with equity, time (savings) deposits, and funds obtained through the sale of securities. On the other hand, Simons [9], who was afraid that securities could become a money substitute and therefore allow the credit investment trusts to continue to create money (cf. [15], p. 210), wanted to limit the money available for loans to the investment trusts' own capital ([7], p. 7). Benes and Kumhof's $([14]$, p. 19,34$)$ latest proposal is closer to Simons insofar as it would give credit investment trusts the opportunity to use equity and treasury credit for their loans.

The third actor in the newest version of the Chicago Plan by Benes and Kumhof is the central bank/treasury. In order to keep the argument simple no clear distinction is made between the central bank and the government ([7], p. 8). It is assumed that this institution would be public and independent. It would control 
the money supply by providing treasury credit and counter-cyclical capital requirements ([7], p. 11, 30; cf. [14], p. 34). It could for example offer treasury credit at negative interest rates in a depression in order to restart the economy ([7], p. 12).

In the transition period between the current fractional reserve banking system and the full reserve banking system-I am again following here Benes and Kumhof s ([14], p. 7) proposal—the central bank/treasury would transfer newly created government-backed money to the private banks, so that they would be able to hold $100 \%$ reserves for their customers' deposits. Furthermore the central bank/treasury would buy back government bonds as well as short-term and mortgage loans from the credit investment trusts in exchange for treasury credit. This would not only eliminate government debts but also the debts of the private banks' customers without changing the amount of money in the economy ([14], p. 8). However, the big difference is that the money created by the private banks under fractional reserve banking would be entirely replaced by official government-backed money. See Table 1 for a summary of all the previously discussed elements of the Chicago Plan.

Advocates of the Chicago Plan suggest that the plan's application would have several positive effects on the economy. For example, Fisher [10] believed that such a reform would eliminate bank runs, a better control of credit cycles, and a significant reduction of government and private debt ([14], p. 4). Benes and Kumhof ([14], p. 8, 55f) are even going beyond Fisher and claim an increase of the long-term output of the economy by 10 percent and the possibility of a more stable monetary policy without liquidity traps. Their dynamic stochastic general equilibrium model supported all of these claims. Furthermore, Kaoru Yamaguchi ([16], p. 417) showed-using an accounting system dynamics approachthat a full reserve banking system would allow the elimination of government debt without "triggering recession, unemployment and inflation." And finally, the Chicago Plan would not diminish the useful core functions of private banks as for example "providing a state-of-the-art payments system, facilitating the efficient allocation of capital to its most productive uses, and facilitating intertemporal smoothing by households and firms" ([14], p. 7).

Table 1. Summary of the Chicago plan.

\begin{tabular}{|c|c|c|c|c|}
\hline & Deposits & Loans & Money Supply & Transition \\
\hline Money Banks & $100 \%$ reserves & - & - & $\begin{array}{c}\text { treasury provides } \\
\text { reserves }\end{array}$ \\
\hline $\begin{array}{c}\text { Credit } \\
\text { Investment } \\
\text { Trusts }\end{array}$ & - & $\begin{array}{l}\text { a) equity }+ \text { time deposits }+ \\
\text { funds obtained through } \\
\text { sale of securities [10] } \\
\text { or b) equity }+ \text { treasury credit } \\
{[14]} \\
\text { or c) equity [9] }\end{array}$ & - & $\begin{array}{l}\text { government bonds, } \\
\text { short-term and } \\
\text { mortgage loans are } \\
\text { cancelled against } \\
\text { treasury credit [14] }\end{array}$ \\
\hline $\begin{array}{c}\text { Central } \\
\text { Bank/Treasury }\end{array}$ & - & - & $\begin{array}{l}\text { provision of } \\
\text { treasury credit }\end{array}$ & - \\
\hline
\end{tabular}


Critics on the other hand have pointed out several problems of the Chicago Plan. The first claim is that most of the benefits (reduced boom and bust cycles as well as price stability) depend on the quality of the subsequent monetary and fiscal policy rather than the full reserve system itself. And this is especially for the Chicago Plan a problem, since it does not make a clear distinction between the central bank and the government. It is therefore not unreasonable to doubt that politicians would have no influence on the money supply ([7], p. 13; cf. [17], p. 10). Another important criticism targets the proposal that the government should cover for private debts. Not only would this have distributional effects, but also it would reward excessive risk-taking behavior ([7], p. 13). The problem with this argument is that the current system, which bails out regularly the too-big-to-fail private banks, has already distributional effects and rewards excessive risk-taking behavior, but it provides the safety net only for Wall Street and not for the main street. Is it not much more reasonable to give the money to the main street, so that they can pay their loans back to Wall Street, instead of giving the money directly to Wall Street and leaving the levels of private debt unchanged? Besides, this debt jubilee is actually also in the interest of the private banks, because many of their assets are worthless, if their borrowers default (cf. [16], p. 487).

The last and most important criticism is that the Chicago Plan does not stop private banks to create money out of thin air ([7], p. 13). The Chicago Plan clearly rules out the creation of bank money as described in the endogenous money theory (private banks can create money without having acquired deposits or other funds first), but at least Fisher's version of the Chicago Plan has two serious problems. The first is that it allows credit investment trusts to fund loans through the sale of securities, which could develop into near-monies. And this full reserve banking system wants to control all forms of money, including money substitutes ([7], p. 13). The second problem is that Fisher proposed to give the credit investment trusts the ability to use time (savings) deposits for loans. This, however, would allow the creation of bank money as described in the money multiplier model. The same amount of money could "be lent, spent, saved and lent out again multiple times" ([7], p. 13), and without reserve requirements for credit investment trusts this process could be repeated infinite times. In other words, the Chicago Plan would have failed to achieve what it wanted. But not all versions of the Chicago Plan have this problem. Benes and Kumhof as well as Simons eliminated this problem by limiting the funding of loans to treasury credit and/or equity.

\section{Sovereign Money}

The origin of the idea of Sovereign Money can be seen in the economic works of Frederick Soddy, who received the Nobel Prize in chemistry in 1921. He distinguished real wealth (means of production) from virtual wealth (money and debt) based on the insight that inescapable entropy laws of thermodynamics (which 
cause depreciation) only apply to real wealth, whereas virtual wealth would compound at the rate of interest. In order to create equilibrium between real and virtual wealth Soddy proposed some type of full reserve banking ([6], p. 4) cf. [18] [19]. The ecological oriented social scientists Herman Daly [20], Michael Rowbotham [21], Joseph Huber and James Robertson [22], and most recently Andrew Jackson and Ben Dyson [23] took up Soddy's ideas and developed the argument further ([6], p. 10f). All Sovereign Money theories aim to give nation-states monetary sovereignty, which includes the prerogative to issue money and to benefit from the seigniorage ([22], p. 39). I will focus here mainly on Jackson and Dyson's Positive Money proposal, which was written in the British context ([6], p. 11) and is a response to the recent financial crisis.

The Sovereign Money approach has the same aim as the Chicago Plan-to abolish the creation of money by private banks and to restore a state monopoly on issuing debt-free money ([23], p. 25; [24], p. 14) —but it tries to achieve this aim in different ways. The first difference is that no break-up of commercial banks into money banks and credit investment trusts is demanded. The second point is the insight that money in our information age is much more than just cash (e.g. credit cards), and therefore the Chicago Plan with the requirement for money banks to hold 100 percent reserves in cash seems to be outdated ([22], p. 4, 23). Since money is today mainly information stored in bank accounts, it is much easier to prevent private banks to use their customers' deposits for creating loans by changing accounting rules (cf. [23], p. 26). The first step is to declare the electronic money in the customers' deposits (most of it was created by the private banks) to be legal tender ([22], p. 23f). In a second step the private banks would be required to make a clear distinction between safe transaction accounts with instant access for the customers and investment accounts "where the customer consciously requests their funds to be placed at risk and invested" ([23], p. 26). Transaction accounts would not anymore be a liability for the private banks ([22], p. 23f). The private banks would keep them only in custody for the customers, "but the money is held off-balance at a central bank database" ([7], p. 15). Private banks would be unable to use those transaction accounts for making loans, and therefore the transaction accounts would be risk-free, but unfortunately also not interest-bearing. Customers would have to pay a fee for the service provided by the private banks ([7], p. 15; [23], p. 180; [24], p. 14).

If customers would want to get interest on their capital, they would need to transfer their money from the safe transaction accounts to investment accounts and from here directly to the banks' investment pool accounts. In this senseand this is important-the investment accounts "will never actually hold any money" ([23], p. 182), "they are the record of the liability that the bank now has towards the customer" ([7], p. 15). Those funds would be available to the private banks for investments in agreed upon risk-categories for a specific period of time, in which the customers would have no access to the money ([23], p. 177f, 182). The ownership of investment accounts would have to be unchangeable in 
order to prevent that they could be used to make payments ([23], p. 184; [24], p. 74). The government would not provide any guarantees for investment accounts, and potential losses would be split between the holder of the investment account and the private bank ([7], p. 15; cf. [23], p. 183, 198). Private banks would become real intermediaries between risk-seeking savers and borrowers by transferring existing money from one group to another ([21], p. 282; [22], p. 2, 25; [23], p. 177; [24], p. 14).

In contrast to the Chicago Plan the Sovereign Money proposal does not need to control money substitutes, because the government would guarantee only the official money- "defined as the sum of all accounts at the central bank" ([7], p. 30; cf. [22], p. 3) - by law "as payment in commerce and for settlement of debts and taxes" ([24], p. 92). Another important difference to the Chicago Plan is the separation of the roles for the central bank, a Money Creation Committee (MCC), and the government. As already described, the central bank would keep the databases for the customer funds accounts and the investment pool accounts as well as several other accounts. It would therefore always know of how much money is in the economy. But the central bank would not decide the amount of money circulating in the economy. This would be done by a newly established MCC, which would be a public and independent institution. The argument for not letting the central bank making this decision is that "neither profit-seeking bankers nor vote-seeking politicians can be trusted with the power to create money" ([23], p. 204), because both groups have a conflict of interest ([23], p. 203). Instead the MCC, which would not profit from the creation of money, would create money by either transferring it to the government or-in order to prevent a lack of credit-by directly lending to the private banks, under the condition that they would lend this money only "to businesses that contribute to GDP" ([23], p. 215), depending on the needs of the economy ([23], p. 204). MCC's aim would be to keep the rate of inflation under control, but the parliament would have the right to change the mandate of the MCC if necessary ([23], p. 205). And finally, the government's role would be to decide how to spend the newly created money, which it would treat as additional revenue ([22], p. 1; [23], p. 211). The government could use this revenue to increase its spending, to reduce taxes, to repay public debt, or to pay a citizen dividend ([22], p. 9; [24], p. 15). Table 2 summarizes the above discussion of the roles of the different institutions in the Positive Money Proposal.

The transition to the new system would consist of two phases. First, on a specified date the demand deposits of private banks will be converted into state currency and the customers' current accounts become transaction accounts, whereas their savings accounts become investment accounts. This conversion can be done over night ([23], p. 219). It would require that the central bank had created the databases in order to keep track of the individual transactions. Since the removal of the transaction accounts from the bank's balance sheet would significantly increase the equity of the private banks, it would be necessary to 
Table 2. Summary of the positive money proposal.

\begin{tabular}{|c|c|c|c|c|}
\hline & Deposits & Loans & Money Supply & Transition \\
\hline Private Banks & $\begin{array}{c}\text { transaction } \\
\text { accounts } \\
\text { held in custody }\end{array}$ & $\begin{array}{l}\text { equity }+ \text { investment pool } \\
\text { account }+ \text { loans from } \\
\text { other banks (incl. loans } \\
\text { from the central bank) }\end{array}$ & - & $\begin{array}{l}\text { 1. switchover of all } \\
\text { current accounts into } \\
\text { state currency } \\
\text { 2. gradual pay down of } \\
\text { conversion liability }\end{array}$ \\
\hline Central Bank & $\begin{array}{c}\text { customer funds } \\
\text { database }\end{array}$ & $\begin{array}{l}\text { investment pool } \\
\text { account database }\end{array}$ & $\begin{array}{c}\text { (lending to } \\
\text { private banks) }\end{array}$ & 1. creating databases \\
\hline MCC & - & - & $\begin{array}{c}\Uparrow \\
\text { determines } \\
\text { quantity } \\
\text { of money } \\
\Downarrow\end{array}$ & - \\
\hline Government & - & - & $\begin{array}{l}\text { (spending money } \\
\text { into economy) }\end{array}$ & - \\
\hline
\end{tabular}

place a Conversion Liability that equals the amount of the removed Transaction Accounts onto to balance sheet ([7], p. 19; cf. [21], p. 262; cf. [22], p. 26; [23], p. 229f). Over a period of 10 to 20 years, the private banks would then have to pay gradually down this Conversion Liability to the central bank, whenever the banks' borrowers would pay their loan back. In the long run this would reduce household debt and the size of the private banks' aggregated balance sheet ([23], p. 219, 230).

Jackson and Dyson claim that their Positive Money proposal would provide the following benefits ([7], p. 20f). It would in the long run reduce the level of debt in the economy. And since saving and lending are disconnected, it would be possible to let banks fail without the need of deposit insurance or taxpayer-funded bailouts ([23], p. 177f, 256). Furthermore, they claim that the control over the money supply could be simplified, because the MCC could directly create or destroy money and would not need to manipulate the interest rate as it is currently the case ([22], p. 15; [23], p. 208, 274). And the independency of the MCC would guarantee the elimination of asset price bubbles and the limitation of monetary sources of inflation ([23], p. 25), and therefore also the regulatory burden could be reduced ([24], p. 16). Additionally, the state would earn a large profit from creating new money, which could be used to stimulate economic growth ([24], p. 12). Furthermore, a single country could implement this new system without the need to coordinate with the rest of the world ([24], p. 17). And finally the monetary and financial institutions will not change dramatically. "Almost all the everyday routines of the banking and financial markets will continue as if nothing had happened" ([22], p. 20). Although, Jackson and Dyson ([23], p. 271) admit that their proposal would reduce the private banks' profits significantly.

But also the Positive Money proposal received criticism. Similar to the counter-argument to the Chicago Plan the independence of the MCC is questioned ([7], p. 22). Jackson and Dyson actually solve this problem much better than the 
Chicago Plan, because the roles of the central bank, MCC, and government are clearly separated. However, this creates concerns about the feasibility of the proposal, since adjustments of the money supply by the MCC would create uncertainty for the government budget, especially if the MCC wants to react immediately to growth cycles in the economy ([7], p. 22). Another problem arises from the transition period, which could benefit the private banks unreasonably. If the private banks would not be required to pay interest on the Conversion Liability, then it would create profits for them, because the Conversion Liability would replace to some degree liabilities, which are interest-bearing ([7], p. 21f). Furthermore, since the Positive Money proposal does not use a debt jubilee as the Chicago Plan, it will take much longer to reach the aim to reduce private debt in the economy. A third criticism forecasts a limitation of the availability of credit. In contrast to the Chicago Plan, the central bank plays in the Positive Money proposal a less important role in lending to the private banks ([7], p. 21). Jackson and Dyson ([23], p. 267f) counter this argument by pointing out that not all investments in our current system are desirable (only 10 percent are for productive investment), that the current system itself produces a shortage of credit during recessions, and finally that an increase in the interest rate should attract new funds from the banks' customers whenever necessary.

However, my biggest concern about the Positive Money proposal is that it does not achieve its goal to guarantee the government's control over the money supply. Yes, the sovereign money approach rules out money creation by the private banks as it was described by the endogenous money theory. But similar to Fisher's version of the Chicago Plan Jackson and Dyson allow private banks to use time (savings) accounts for making loans. This would imply that money creation as in the money multiplier theory would be still possible. This is countered to some degree by the rule that the customers' Investment Accounts do not hold any money, but it would still increase the velocity of money ([22], p. 48; [23], p. 252). An example can show this result (see Figure 1). Let us assume that we have only $\$ 1000$ in our economy in the hands of Lender A. In a first step Lender A transfers his money from his Transaction Account to his Investment Account and therefore directly to the bank's Investment Pool Account. The bank now gives in a second step a credit of $\$ 1000$ to Borrower $\mathrm{A}$, who buys with this money something from Lender B. In a forth step, Lender B transfers this money to his investment account, which again ends up in the bank's Investment Pool Account. And the private bank gives another credit of $\$ 1000$ to Borrower B. This process could be repeated infinite times, since no reserve requirements exist anymore ([23], p. 269).

In this example, the amount of electronic money hold in the central bank's database has not changed. It is still $\$ 1000$. But the values of the customers' Investment Accounts and the outstanding loans have doubled. And obviously the private banks have a strong interest in repeating this process as often as possible, because it increases their short-term profits. Jackson and Dyson ([23], p. 252) 

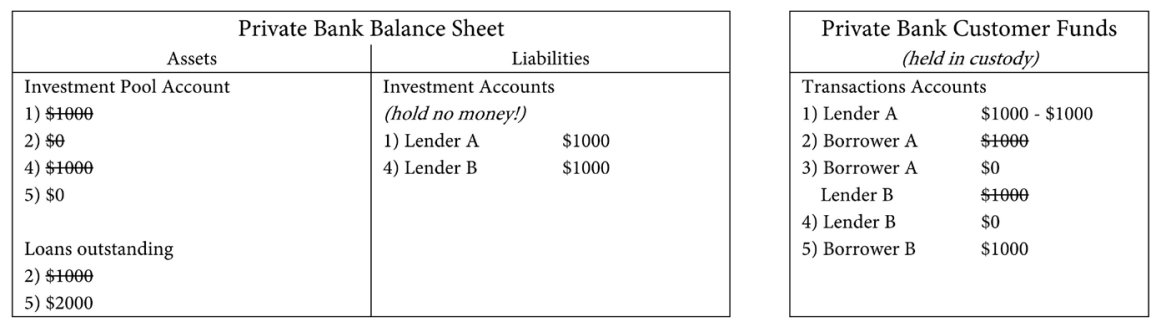

Figure 1. Money Creation in the positive money proposal.

downplay this problem by arguing that such a "process is unsustainable in the long term." I agree, it is. In the moment the process becomes unsustainable and borrowers default, the bubble will burst with consequences for the real economy. It would not destroy money, but we can expect that the private bank's customers, who lost their "wealth" in the Investment Accounts will adjust their behavior and cut consumption. This problem becomes more serious, because Jackson and Dyson ([23], p. 266) admit that a positive inflation rate would actually turn into a negative real interest rate for money on Transaction Accounts, since it would not anymore be interest-bearing. And "this should incentivize people to place money they are not spending into Investment Accounts." Imagine all the poor people, who try to protect their little savings from inflation and finally realize that they have lost everything. It is very likely that governments would intervene again in order to avoid the political fallout. And this was exactly what the Positive Money approach tried to avoid.

\section{Modern Money Theory}

The Modern Money Theory (MMT) was developed by a group of economists around Randall Wray in the neo-Chartalist tradition of post Keynesianism. It combines “J.M. Keynes's analysis of monetary production economy, Abba Lerner's theory of Functional Finance (FF), Hyman Minsky's Financial Instability Hypothesis (FIH), Wynne Godley's Sectoral Balance (SB) approach to macro modeling, and the work of G.F. Knapp and A. Mitchell Innes, who independently developed chartalist or state theories of money" ([25], p. 9).

MMT shares with both the Chicago Plan and the Sovereign Money approach the idea that states should be in charge of creating money. However, advocates of MMT have developed this argument under chartalist influence further. The first claim is that the consolidated government (including the Treasury and the Central Bank ([25], p. 5; [26], p. 78)) has the power to create money that people will use in their daily transactions, because it has the authority to decide that the citizens have to settle their taxes in this money ([27], p. 69, 75). But in order for the citizens to pay their taxes in state money, it is necessary that the state has spent this money into existence before the taxes are paid. "Government spending comes prior to taxation" ([25], p. 4; [26], p. 70; [27], p. 80). This view is in opposition to the common standpoint that the collection of taxes is necessary in order to finance government expenses, which leads to the conclusion that 
long-term government deficits are bad for the economy. Instead the MMT argues that long-term government surpluses are bad for the economy, because it would drain the money out of the economy, since taxes reduce and government spending increases the amount of money circulating in the economy ([27], p. 75, 80). A growing economy, which needs an expanding stock of money, would therefore require the state to run budget deficits. Furthermore, if the private sector wants to save money-the money would be taken out of circulationstate money would have to increase through additional government spending ([26], p. 78). And governments do not need to borrow money. They can just spend it into existence ([26], p. 70, 78). "The market demand for currency, therefore, determines the size of the deficit" ([26], p. 78). As long as a state does not issue debts in a foreign currency, the constraints from international markets are only imagined and result "from a misunderstanding of the nature of government deficits" ([27], p. 75, cf. 169).

The chartalist approach argues further that the government-as a monopolist over its currency-has the power to set prices ([26], p. 71). This is possible, because the government does not need to buy at market prices ([27], p. 93). It can set "unilaterally the terms of exchange that it will offer to those seeking its currency" ([28], p. 174). For example, if the government would buy a good above the market price, then it would increase the market price for this good, since the private sector would need to pay more in order to continue to consume this good. On the other hand, if the government would set their price below the market price, then very likely private suppliers would not anymore sell to the government. This, however, reduces government spending and therefore the money supply (assuming that tax payments stay the same). This would lead to deflation until the market price would fall to the price level set by the government. In this sense, by refusing to change the prices the government is going to pay for goods, it will counter-act inflationary or deflationary pressures ([27], p. 93). However, the government is not required to set the prices of all goods. It would be enough to set the price of one important commodity "that enters as a major cost in the private sector" ([27], p. 94) in order "to anchor the value of its currency" ([26], p. 81). In this proposal inflation could only occur under full employment, if the government increases the aggregate demand by increasing spending or by reducing taxes or if the private sector reduces savings ([27], p. 123; [29], p. 18). In the chartalist view, "inflation would result, if the relation between government spending and taxing were wrong, not because the ratio of money supply (however measured) and GDP were wrong" ([29], p. 9).

The same logic can be applied to unemployment. Involuntary unemployment increases, whenever the additional money supply (government spending minus taxes) is not enough to cover the private sector's additional savings, which in aggregate reduces the money available for productive uses ([26], p. 81; [27], p. 84; [30], p. 176f). However, the problem is that the government does not know in advance how much the private sector wants to save, and therefore cannot ad- 
just government spending or taxes in time. In order to solve this problem chartalists argue that governments should implement Abba Lerner's "functional finance" approach ([26], p. 82). Functional finance requires governments to adjust their spending to the rate at which "the current prices would buy all the goods that it is possible to produce" ([31], p. 39). "Spending below this level results in unemployment, while spending above it causes inflation" ([26], p. 82). Randall Wray ([27], p. 76f) argued that this could be achieved with a government job opportunity program or an employer of last resort (ELR) program.

The ELR is a government program that offers everybody, who is ready, willing and able to work, a job at a fixed wage ([26], p. 82; [27], p. 124). By doing so the government sets the price for unskilled labor, which is an important commodity for the private sector, and therefore anchors the value of its currency ([27], p. 94, 131 ; [30], p. 175). "[T] value of the currency is determined by what one must do to obtain it, and with ELR in place, it is clear exactly what that is: the value of the currency is equal to one hour of ELR work at the going ELR wage" ([26], p. 82). In addition, the ELR fulfills the principle of functional finance, because government spending would float counter cyclically. In times of high unemployment the ELR will increase government spending automatically, whereas in times of full employment the ELR will reduce government spending and inflationary pressures ([26], p. 83; [27], p. 94; [32], p. 15). However, the ELR would allow the firing of workers, if they would not fulfill the required performance standards ([27], p. 125). As a result, we can expect the ELR to be better than unemployment, because "it would prevent deterioration of labor skills, would maintain income at a base level" ([32], p. 15), and "should lower recruiting and hiring costs as employers would have an employed pool of workers demonstrating readiness and willingness to work" ([29], p. 46f). Workers, who are unwilling or unable to work, would still have to rely on the social safety net ([27], p. 125).

Finally, the advocates of the MMT claim that their proposal would be compatible to a free market ideology, because government interventions could be reduced. Neither would there be a need for a minimum wage law, nor would the interest rate need to be adjusted frequently. And since the ELR reacts automatically to the private sector's demand of labor, it is actually the private sector that decides the size of the government's deficit ([27], p. 182).

The critics of the MMT have mainly focused on two topics. The first is related to concerns about the applicability of the ELR program in real economies. Critics question whether the government can find sufficient desirable work for all the unemployed workers ([27], p. 181) or believe that it would lead to inflation, since those "unproductive" workers in the ELR would earn wages and consume goods, although they do not increase the production of those goods ([29], p. 47). Wray ([27], p. 182) counters the former point by referring to the endless job opportunities in the not-for-profit, volunteer organizations as a way to find desirable work. And the counter-argument to the latter point is that the ELR as well as any other service job does not produce any goods. Should we therefore get rid of all service jobs? According to Tymoigne and Wray ([29], p. 48) this 
argument is a red herring.

The second concern of the critics is far more serious. More mainstream post Keynesians have pointed out that the role of private banks in creating money is not covered well in MMT ([33] [34], p. 19). This is an important issue, since the MMT emphasizes the view that the government has a monopoly to create money, which however is not the case in reality. It is even more confusing that the MMT makes this argument in the context of post Keynesianism, which believes in its core in the endogenous money theory [35]. The advocates of MMT have replied to this criticism that they tried to add the state to the mainstream post Keynesian analysis ([25], p. 2). And this is possible, because private banks "cannot get hold of [state money] for clearing (or, to meet reserve requirements) unless the state lends or has spent [state money] into existence" ([25], p. 3). This, however, sounds like the money multiplier theory and not the endogenous money theory ([33], p. 61; [35]) —an interpretation, which is strongly rejected by Tymoigne and Wray ([29], p. 36f). I have to admit, I am confused too. MMT cannot be applied in an economy that allows endogenous money creation, because the state has no monopoly over the money supply. Unfortunately, it can also not be applied to an economy that gives the private banks the permission to multiple state money, if the state does not close the loopholes to go beyond the reserve requirements: securitization.

\section{Synthesis}

Martin Wolf ([15], p. 221f) remarked that the views on monetary policy of the Chicago Plan, the Sovereign Money approach, and MMT are very similar. All three theories claim that the state should create money, although their proposals are quite different in the details. However, all three approaches have serious weaknesses. The major issue of both the Chicago Plan and the Positive Money proposal is that they cannot guarantee the independence of the institution, which is going to determine the money supply. On the other hand the advocates of MMT do not understand that their theoretically sound plans to create a countercyclical ELR program cannot be applied to real economies as long as they allow private banks to create money ([36], p. 53). It seems to me that the Chicago Plan and the Positive Money proposal could solve the key problem of MMT, whereas MMT could solve the main problem of the Chicago Plan and the Positive Money Proposal. They actually complement each other well. I will try to describe here a synthesis of the three approaches, which I will call the Modern Sovereign Money synthesis (see Table 3).

First of all, considering that we are living in an information age, I agree with the Sovereign Money theorists that it is much easier to change accounting rules than printing a large amount of cash in order to introduce a $100 \%$-reserve requirement. I would follow here largely the Positive Money proposal of Jackson and Dyson (see Table 2). Central banks would keep the databases (customer funds, investment pool, etc.), whereas the private banks would hold the Transaction 
Table 3. Summary of the modern sovereign money synthesis.

\begin{tabular}{|c|c|c|c|c|}
\hline & Deposits & Loans & Money Supply & Transition \\
\hline Private Banks & $\begin{array}{l}\text { transaction accounts } \\
\text { held in custody }\end{array}$ & $\begin{array}{l}\text { equity }+ \text { loans from } \\
\text { other private banks }\end{array}$ & - & $\begin{array}{l}\text { a) switchover of all current accounts into } \\
\text { state currency } \\
\text { b) government bonds, short-term and } \\
\text { mortgage loans are cancelled against central } \\
\text { bank credit }\end{array}$ \\
\hline Public Banks & $\begin{array}{l}\text { transaction accounts } \\
\text { held in custody }\end{array}$ & $\begin{array}{l}\text { loans from the } \\
\text { central bank }\end{array}$ & - & - \\
\hline Central Bank & $\begin{array}{l}\text { customer funds } \\
\text { database }\end{array}$ & $\begin{array}{l}\text { investment pool } \\
\text { account database }\end{array}$ & $\begin{array}{c}\text { (lending to } \\
\text { public banks) }\end{array}$ & change of the balance sheet \\
\hline $\begin{array}{l}\text { Employer of } \\
\text { Last Resort }\end{array}$ & - & - & $\begin{array}{c}\Uparrow \\
\text { counter-cyclical job } \\
\text { opportunity program } \\
\Downarrow\end{array}$ & - \\
\hline Government & - & - & (budget deficit) & - \\
\hline
\end{tabular}

Accounts in custody. However, I would deviate from the Positive Money proposal in two aspects. The first is that I prefer an immediate elimination of all debt as in the Chicago Plan rather than using a Conversion Liability, which would have to be paid back for at least 10 - 20 years. It is not only faster, but it also removes the insecurity in relation to the outstanding private debt. Furthermore, as I already mentioned above, I think that it is smarter to the let the private banks' borrowers pay back their loans instead of bailing out the private banks without changing the level of private debts. The latter does not solve the problem, because the private sector would be still indebted. In order not to punish debt-free (or less indebted) households or companies, which were more responsible, those households or companies could get tax-reductions for a specific transition period. As a result, the households or companies, which would be bailed out by taxpayers-money, would have to pay more taxes in the future.

My second concern about Jackson's and Dyson's Positive Money proposal is that they would like to give the private banks the permission to use time deposits for creating loans. As I have shown above, private banks could still increase the velocity of money similar to the money multiplier model. This is not acceptable for me. I prefer Benes's and Kumhof's Chicago Plan, which would restrict private banks to use only equity and loans from other banks for loan creation. This is the only solution that guarantees the state monopoly of creating money. However, this solution would lead to another problem. Jackson and Dyson ([23], p. 181) have emphasized that the Transaction Account fees could be expected to be very low, since the private banks would compete for customers in order to get their lucrative time deposits for making loans. But if the private banks have no access to time deposits for the purpose of making loans, then they also loose the incentive to compete for customers with cheap Transaction Accounts. By forming a cartel, they could actually turn this into an opportunity to increase profits, especially if everybody needs to have a Transaction Account, because money ex- 
ists only in digital form. The costs for the bank account owners could increase significantly. In order to avoid this negative outcome, I propose the creation of public not-for-profit banks (if they not already exist as in Germany). Those public banks could offer Transaction Accounts at fees that only cover the costs. The competition would force private banks to offer the same service more efficiently in order to earn a profit.

The creation of public banks could also solve another important issue. The prohibition of private banks to make loans by using deposits would very likely reduce the availability of credit in the economy ([7], p. 3; [17], p. 4; [37], p. 66; [38], p. 262). In order to avoid negative effects on investments, public banks could fill in and provide credit for the companies that want to create jobs. Public banks would be able to receive unlimited loans from the Central Bank for this purpose. However, they would not be allowed to create money for mortgages or car loans. If somebody wants to borrow money for consumption, he/she would still need to borrow from the private banks (which would have no access to cheap unlimited Central Bank loans). The main advantage of such a system is that it breaks the connection between savings and investments (the available money for investments would be in principle unlimited). Of course, paying interest and repaying loans would reduce the money supply. In order to avoid this outcome, the reduction of the money circulating in the economy would have to be counter-balanced by an equivalent increase of the government budget.

The usual argument against public banks is that they are inefficient compared to the private banks. Well, I would immediately ask how efficiency is measured. Of course, the proposed public banks would be much less efficient in making a profit. This should not be a surprise, since it would not be their aim to make profit. On the other hand, I am quite sure that those public banks would be much more efficient in supporting the creation of jobs and with this the sustainable growth of the economy than private banks [39]. The main reason for this is that both public and private banks have a principal-agent problem ([4], pp. 197-198; [40], p. 28). The principal-agent problem describes a situation in which the owners of an organization (the principal) are delegating the power to make operative decisions to top managers (the agent). And since the agents have detailed knowledge of the operative business it becomes difficult for the principals to control them. In other words, the degree to which the agents fulfil the aims of the principals depends on the incentive structure. Currently the incentive structure for bankers in private banks provides high bonuses for short-term profits, even if their decisions destroy the banks in the long run (the principals lose all their capital, but the agents do not need to pay back their bonuses) ([4], p. 155). Short-term profits can be increased dramatically by gambling with derivatives and not by lending to the real economy. The incentive structure in private banks does therefore not support the efficient creation of jobs. On the other hand, it would be easy to establish an incentive structure in public banks that encourages bankers to lend money to reasonable and sustainable businesses. 
Bonuses for public bankers should depend on the number of jobs created (positive relation) and on the amount of money that got lost as a result of default (negative relation). The second component is important in order to avoid wasteful investments into unreasonable projects which might create a lot of jobs in the short-term, but which quickly end into bankruptcy. Such an incentive structure in public banks would much more efficiently support the creation of jobs than the profit-oriented private banks.

The final problem is the question of who should have the authority to decide the right amount of money supply. Unfortunately, neither the politicians nor the central bankers can be trusted. Politicians have a conflict of interests, since they have a motivation to hand out favors in order to win elections. Central bankers on the other hand have a conflict of interest, because many central bankers have personal connections to private banks. This problem increases significantly in countries, where the private banks as for example in the United States own the Central Bank. The ideal solution is the ELR of the Modern Money Theory, because nobody would be in charge. The amount of workers in the ELR could automatically determine the interest rate at which customers of the public banks would borrow money for investments. The closer the economy moves towards full employment the higher the interest rate should become, in order to weed out the less efficient projects. And if full employment could be reached, the public banks would stop lending money. Additionally, the size of the ELR could also determine the government's budget deficit (or surplus) once or twice a year. An extensive ELR program should lead to a high budget deficit, whereas a small ELR program should reduce the money supply by requiring a budget surplus. It would be enough to adjust the government's budget only once or twice a year, because the ELR itself as well as the public banks' lending would react immediately to changes in the demand for money.

I would like to mention that this proposed system solves another criticism against the Chicago Plan or the Positive Money proposal. It is often argued that any type of full reserve banking reform would reduce the profits of private banks so much that they would be driven into the unregulated shadow banking sector ([7], p. 34; [17], p. 9; [37], p. 66; [41]). From this point of view, radical reforms seem to be a bad idea, since the shadow banking sector contributed largely to the mortgage bubble and the Lehman Brothers crash. However, what the critics hold back is that the shadow banking sector was fueled by (private) bank money through securitization. But this would not anymore be possible under the Chicago Plan, the Positive Money approach, or my proposed synthesis. Of course, the shadow banking sector could still create their own monies as everybody else could create their own money (cryptocurrencies are an example). The difference is, however, that those monies would not be accepted for paying taxes and would not be guaranteed by the state. The acceptance of those monies would depend on the credit- and trustworthiness of the issuer. It is very unlikely that those private currencies would play a major role in any economy. And even if they would, the 
ELR program in my synthesis would react to an increase in the "money" supply by private issuers. The result would be a reduction of the supply of official state money, which again implies that it would become harder to acquire the official money in order to pay taxes. The value of the private currencies would decrease in relation to the official money. And this tendency would become stronger the more private money would be issued. It is only a question of time that the trust in the private currency would crumble and it would disappear. The ELR program would immediately adjust again and produce more official money in order to fill the gap. Privately issued currencies are not a problem. It is not even necessary to regulate them, because the government's threat not to bail-out shadow banks is credible.

This alternative monetary system, which relies on a synthesis of the Chicago Plan, the Sovereign Money approach, and the Modern Money Theory, could enable sustainable growth without the necessity of introducing a strict regulatory system for private banks. The basic conflict of interest in a fractional reserve banking system between the private banks and society as a whole would disappear. As a result this alternative financial system would much more efficiently contribute to economic growth and the reduction of unemployment than the current system. It would much better fulfil the aim of price stability than the current system. Furthermore, the money available for speculation would dry up immediately when private banks would lose the ability to create money. And the establishment of such an alternative financial system would not require international cooperation, because it would make the national public banking sector largely independent from other financial markets.

\section{Conclusions}

The focus of the first part of this series [1] was on an analysis of the private banks' current ability to create money. I have shown that independent of the theory, which explains this money creation process (money multiplier theory vs. the post Keynesian endogenous money theory), issuing of money by private banks leads to a fundamental conflict between the risk-seeking bankers and the risk-averse society. Private banks can increase their profits by extending the money supply through loans. The society on the other hand has an interest to limit the money creation by the private banks, because the excessive issuing of (private) bank money increases the probability of bursting bubbles and bank runs with tremendous negative consequences for the real economy and the taxpayers. Furthermore, I argued that the conventional proposals to reduce the risks of financial crises would fail, because they did not address the cause of the issue: the fundamental conflict between private banks and the society.

In this second part, I analyzed the more radical proposals, which actually tried to solve this fundamental conflict. Both the Chicago Plan as well as the Sovereign Money approach claim that they would achieve this by abolishing fractional reserve banking. On the other hand, the Modern Money Theory claims in the 
chartalist tradition that an employer of last resort program would solve the issue. The rather shocking result of my analysis is that all three approaches fail to overcome the fundamental conflict between private banks and society. The major flaw of the Positive Money proposal and at least Fisher's Chicago Plan is that they still allow private banks to create money in the sense of the money multiplier model. Furthermore the Chicago Plan and the Sovereign Money proposals cannot guarantee an independent and impartial money supply. And the main problem of the Modern Money Theory is that it neglects how private money creation interferes with their chartalist approach. Finally, I proposed a synthesis of those three theories in order to fix their problems. This Modern Sovereign Money proposal combines the Positive Money's accounting rules for electronic money with the Chicago Plan's fast transition and the Modern Money Theory's employer of last resort program.

The Modern Sovereign Money synthesis makes it impossible for private banks to create money and to change the money's velocity. It guarantees safe deposits for the bank customers, and it would keep prices stable. It provides unlimited loans for investment by detaching investments from saving. And financial crises would have no impact anymore on the real economy. As a result, governments would not anymore be forced to bail-out failing banks. And all of this could be achieved without strict regulations for private banks.

\section{Conflicts of Interest}

The authors declare no conflicts of interest regarding the publication of this paper.

\section{References}

[1] Etzrodt, C. Modern Sovereign Money-Part I, The Moral Hazard of Fractional Reserve Banking. Open Journal of Social Sciences. (In Press)

[2] Cook, R.C. (2010) The Democratization of the Monetary System. In: Chossudovsky, M. and Marshall, A.G., Eds., The Global Economic Crisis, Global Research, Montreal, 355-363.

[3] Brown, E. (2010) Wall Street's Ponzi Scheme. In: Chossudovsky, M. and Marshall, A.G., Eds., The Global Economic Crisis, Global Research, Montreal, 367-374.

[4] Stiglitz, J.E. (2010) Freefall. Norton, New York.

[5] Brown, E. (2008) The Web of Debt. 3rd Edition, Third Millenium Press, Baton Rouge.

[6] Lainà, P. (2015) Proposals for Full-Reserve Banking: A Historical Survey from David Ricardo to Martin Wolf. Economic Thought, 4, 1-19.

[7] van Dixhoorn, C. (2013) Full Reserve Banking. Sustainable Finance Lab, Utrecht.

[8] Simons, H., et al. (1933) Banking and Currency Reform. Manuscript. [Reprinted in Samuels, W., Ed. (1990) Research in the History of Economic Thought and Methodology. Archival Supplement, Volume 4, JAI Press, Greenwich.]

[9] Simons, H. (1948) Economic Policy for a Free Society. University of Chicago Press, Chicago. 
[10] Fisher, I. (1935) 100\% Money. Adelphi Company, New York.

[11] Friedman, M. (1948) A Monetary and Fiscal Framework for Economic Stability. American Economic Review, 38, 245-264.

[12] Friedman, M. (1960) A Program for Monetary Stability. Fordham University Press, New York.

[13] Friedman, M. (1969) The Optimum Quantity of Money and other Essays. Aldine, Chicago.

[14] Benes, J. and Kumhof, M. (2012) The Chicago Plan Revisited. IMF Working Paper No. $12 / 202$.

[15] Wolf, M. (2014) The Shifts and the Shocks. Penguin Books, London.

[16] Yamaguchi, K. (2016) Money and Macroeconomic Dynamics. 3rd Edition, Japan Futures Research Center, Awaji Island.

[17] Dow, S., Johnson, G. and Montagnoli, A. (2015) A Critique of Full Reserve Banking. Sheffield Economic Research Paper Series No. 2015008.

[18] Soddy, F. (1926) Wealth, Virtual Wealth and Debt. George Allen \& Unwin, London.

[19] Soddy, F. (1934) The Role of Money. George Routledge and Sons, London.

[20] Daly, H. (1980) The Economic Thought of Frederick Soddy. History of Political Economy, 12, 469-488. https://doi.org/10.1215/00182702-12-4-469

[21] Rowbotham, M. (1998) The Grip of Death. Jon Carpenter, Charlbury.

[22] Huber, J. and Robertson, J. (2000) Creating New Money. New Economics Foundation, London.

[23] Jackson, A. and Dyson, B. (2012) Modernising Money. Positive Money, London.

[24] Sigurjónsson, F. (2015) Monetary Reform: A Better Monetary System for Iceland. Report Commissioned by the Prime Minister of Iceland.

[25] Fullwiler, S., Kelton, S. and Wray, L.R. (2012) Modern Money Theory: A Response to Critics. http://ssrn.com/abstract=2008542 https://doi.org/10.2139/ssrn.2008542

[26] Tcherneva, P.R. (2006) Chartalism and the Tax-Driven Approach to Money. In: Arestis, P. and Sawyer, M.C., Eds., A Handbook of Alternative Monetary Economics, Edward Elgar, Cheltenham, 69-86.

[27] Wray, L.R. (1998) Understanding Modern Money. Edward Elgar, Cheltenham.

[28] Mosler, W. and Forstater, M. (1999) General Framework for the Analysis of Currencies and Commodities. In: Davidson, P. and Kregel, J., Eds., Full Employment and Price Stability in a Global Economy, Edward Elgar, Cheltenham, 166-177.

[29] Tymoigne, E. and Wray, L.R. (2013) Modern Money Theory 101: A Reply to Critics. Levy Economics Institute, Working Papers Series No. 778. https://doi.org/10.2139/ssrn.2348704

[30] Mosler, W. (1997-98) Full Employment and Price Stability. Journal of Post Keynesian Economics, 20, 167-182. https://doi.org/10.1080/01603477.1997.11490146

[31] Lerner, A.P. (1943) Functional Finance and the Federal Debt. Social Research, 10, 38-57.

[32] Wray, L.R. (2000) The Neo-Chartalist Approach to Money. https://doi.org/10.2139/ssrn.1010334

[33] Rochon, L.-P. and Vernengo, M. (2003) State Money and the Real World: Or Chartalism and Its Discontents. Journal of Post Keynesian Economics, 26, 57-67.

[34] Palley, T.I. (2013) Money, Fiscal Policy, and Interest Rates: A Critique of Modern 
Monetary Theory. IMK Working Paper, No. 109.

[35] Febrero, E. (2009) Three Difficulties with Neo-Chartalism. Journal of Post Keynesian Economics, 31, 523-541. https://doi.org/10.2753/PKE0160-3477310308

[36] Huber, J. (2017) Sovereign Money. Palgrave Macmillan, London. https://doi.org/10.1007/978-3-319-42174-2

[37] Diamond, D.W. and Dybvig, P.H. (1986) Banking Theory, Deposit Insurance, and Bank Regulation. Journal of Business, 59, 55-68. https://doi.org/10.1086/296314

[38] King, M. (2016) The End of Alchemy. Little Brown, London.

[39] Brown, E. (2012) Public Sector Banks. http://www.globalresearch.ca/index.php?context=va\&aid=29662

[40] Simon, H.A. (1991) Organizations and Markets. Journal of Economic Perspectives, 5, 25-44. https://doi.org/10.1257/jep.5.2.25

[41] Krugman, P. (2014) Is a Banking Ban the Answer? https://krugman.blogs.nytimes.com/2014/04/26/is-a-banking-ban-the-answer/ 